\title{
STUDY OF SOME DIRECT AND IN-DIRECT SELECTION INDICES IN B. campestris $\mathbf{L}$.
}

\author{
Hafiz Basheer Ahmad ${ }^{1, *}$, Hafeez Ahmad Sadaqat ${ }^{1}$, Muhammad Hammad Nadeem Tahir ${ }^{1}$ \\ and Bushra Sadia ${ }^{2}$ \\ ${ }^{1}$ Department of Plant Breeding and Genetics, University of Agriculture, Faisalabad-38040, Pakistan; ${ }^{2}$ Centre of \\ Agricultural Biochemistry and Biotechnology, University of Agriculture, Faisalabad- 38040, Pakistan. \\ "Corresponding author's e-mail: easahafiz@yahoo.com
}

\begin{abstract}
The present study was conducted to estimate the selection indices directly and indirectly involved in yield of B. campestris. Parent lines, $36 \mathrm{~F}_{1}$ hybrids and commercial hybrids/varieties were sown in the field in a randomized complete block design with three replications. Analysis of variance revealed remarkable differences among genotypes. Number of siliquae per plant had the highest heritability followed by days to maturity. Higher genetic advance was recorded for the 100 seed weight and plant height. Glucosinolates had the highest heritability and erucic acid had the highest genetic advance as percent of mean. Correlation studies showed that genotypic associations were higher than phenotypic associations. Plant height, green biomass, number of siliquae, days to $50 \%$ siliquae formation, number of seed per siliqua had considerable relationship with seed yield. Oil content had positive significant correlation with total protein contents. Protein contents had considerable positive correlation with glucosinolate and erucic acid. Glucosinolate had significant positive correlation with erucic acid. Path coefficient analysis showed that harvest index, days to flowering initiation, days to maturity, secondary branches, number of siliquae per plant and seed per siliqua had direct effect on seed yield. Protein content and oleic had direct positive effect on oil content. Therefore, these direct and indirect indices i.e. plant height, green biomass, harvest index, secondary branches, number of siliquae, days to $50 \%$ siliqua formation and number of seeds per siliqua needs emphasis for improvement of seed yield while protein content and oleic acid for oil content.
\end{abstract}

Keywords: Oilseed, canola, genetic variability, heritability, genetic advance, path analysis

\section{INTRODUCTION}

Oilseed Brassicas, rapeseed and mustard, are rich source of vegetable oil, contribute $12-14 \%$ of world total production and is the third largest source after palm and soybean (Wittkop et al., 2009). Brassica species not only contain vitamins and dietary fiber but also anticancerous compounds (Fahey and Talay, 1999).

Brassica campestris belongs to Brassicaceae/Cruciferae family. The name cruciferae had been given due to flower shape that has four diagonal opposite petals like cross. It is believed that cultivated $B$. campestris developed from a wild strain B. campestris, originated from Western Europe to China (Gupta and Pratap, 2007)

Although B. campestris has been cultivated as an oilseed crop in subcontinent and yet not known as wild form in Pakistan and India. Breeding of rapeseed for low erucic acid and glucosinolate was started in Canada and Europe in 1960. Canola is high quality and modern form of oilseed brassicas. It was started in Canada from genetic modification in rapeseed through plant breeding. The first cultivar with "double low" was developed in 1970. The name canola was trademark (Uppstrom, 1995).
The knowledge of the genetic variability, its extent and kind of relationship of quantitative traits in rapeseed and mustard is necessary for a resourceful breeding program. The use of quantitative genetic variability plays an important role for high yielding varietal development and advancement of the economically importance traits (Mahmood et al., 2003). The relationship of seed yield components and quality traits are of main interest. Genetic variations, association and heritability have been studied for quantitative and qualitative traits in different genotypes of rapeseed. Immediate selection for seed, oil yield and protein content might be rewarding for improving oil and protein yield (Khan et al., 2006; Aytac and Knac, 2009).

Genetic advance and heritability are the direct selection criteria that determine the degree to which trait respond to selection. So, for achieving further improvement, it is necessary to determine the genotypic and environmental effects for the trait being considered. High genetic advance along with high heritability indicate the additve gene action and selection would be effective through different selection methods such as pure line selection,mass selection, hybridization and pedigree selection while low heritability with low genetic advance leads to higher influence of environment and selection would be ineffective. Correlation 
coefficient and path analysis in plant breeding describes the relationship between different plant parameters and component traits on which selection can be relied for genetic improvement of yield. Basic information as the magnitude, phenotypic and genotypic pattern, heritability and association of yield contributing traits would be helpful in species improvement along with the selection of suitable breeding method (Marjanović-Jeromela et al., 2011).

\section{MATERIALS AND METHODS}

Hybridization for the present studies was done at intraspecific level. For this purpose ten varieties/lines of $B$. campestris were sown in the field and crossed in line $\times$ tester fashion following Kempthorne (1957). The genotypes including UAF-11, UAF-12, Span, Quinyou-15, TR-8, 1072 and Toria were used as lines whereas Candle, Torch and Tobin were used as testers. All the breeding material so produced at intraspecific level, parent genotypes, $\mathrm{F}_{1}$ hybrids, and commercial hybrids/varieties being were sown in field in a randomized complete block design with three replications. Sowing was done with the help of wooden dibbler using 4-5 seeds per hill, maintaining plant to plant distance of $15 \mathrm{~cm}$ and row to row distance of $45 \mathrm{~cm}$. Only one plant was kept per hole after repeated thinning. Recommended dose of fertilizer, plant protection measures and number of irrigations were applied. Ten plants were tagged in each entry in each experimental unit and the data were recorded on morphological, phenological, seed yield and quality related traits from the tagged plants. Genetic correlations were estimated for all combinations considering morphological, phenological and quality traits following Kwon and Torrie (1964) and path coefficient analysis was performed following Dewey and Lu (1959) using the R program. Broad sense heritability was computed according to Weber and Mort-hy (1952) and genetic advance was calculated at $20 \%$ selection intensity $(\mathrm{i}=1.4)$ according to formula (Poehlman and Sleper, 1955).

\section{RESULTS}

Direct selection indices for quantitative and qualitative traits intraspecific combinations: Analysis of variance for quantitative and qualitative traits showed highly significant differences among the genotypes (Table 1). Heritability and genetic advance are remarkable direct selection indices. The results for quantitative traits (Table 2) shows that days to flowering initiation had high heritability (97.80) along with high genetic advance (32.97) in percentage of meanwhile days to $50 \%$ flowering indicated high heritability (71.29) and remarkable genetic advance (56.10) in percentage of mean which indicated additive gene effects. Days to $50 \%$ siliqua formation, days to maturity and plant height showed considerable heritability and genetic advance. Number of primary branches, secondary branches, biomass, yield and harvest index revealed high heritability with low genetic advance in percentage of mean that showed non-additive gene action and selection which will not be rewarding in early generations. Number of siliqua per plant and number of seed per siliqua had high heritability and remarkable genetic advance in percentage of mean that revealed additive genetic effects. For qualitative (Table 3) oil contents had high heritability (94.70) and moderate genetic advance (17.7) that

Table 1. Mean square values associated with different plant traits of $B$. campestris.

\begin{tabular}{|c|c|c|c|c|}
\hline Source of variation & & Replications & Genotypes & Error \\
\hline Degree of freedom & & 2 & 30 & 60 \\
\hline \multirow[t]{5}{*}{ Phenological traits } & Days to flowering initiation & 11.36 & $36.12 * *$ & 2.92 \\
\hline & Days to $50 \%$ flowering & 5.83 & $29.85 * *$ & 5.21 \\
\hline & Days to $50 \%$ siliqua formation & 2.78 & $30.16 * *$ & 1.51 \\
\hline & Days to maturity & 14.91 & $26.90 *$ & 2.04 \\
\hline & Plant height & 45.20 & $2262.17 * *$ & 16.77 \\
\hline \multirow[t]{4}{*}{ Morphological traits } & Primary branches & 0.90 & $15.33^{*}$ & 1.81 \\
\hline & Secondary Branches & 0.72 & $87.24 * *$ & 1.52 \\
\hline & Green Biomass & 20.20 & $1787.73 * *$ & 7.78 \\
\hline & Harvest index & 4.57 & $1115.77 * *$ & 6.01 \\
\hline \multirow[t]{4}{*}{ Yield related traits } & Number of siliquae per plant & 0.46 & $44.96 * *$ & 1.59 \\
\hline & Number of seed per siliqua & 4.10 & $12343.40 * *$ & 43.70 \\
\hline & 100 seed weight & 15.12 & $20.23 *$ & 10.43 \\
\hline & Seed yield per plant & 1.32 & $423.20 * *$ & 0.45 \\
\hline \multirow[t]{5}{*}{ Quality related traits } & Oil contents $(\%)$ & 0.04 & $37.98 * *$ & 0.69 \\
\hline & Protein contents $(\%)$ & 0.50 & $15.96 * *$ & 1.90 \\
\hline & Glucosinolates (\%) & 5.11 & $1915.00 * *$ & 5.93 \\
\hline & Oleic acid $(\%)$ & 47.26 & $511.02 * *$ & 20.80 \\
\hline & Erucic acid (\%) & 5.58 & $521.88 * *$ & 3.82 \\
\hline
\end{tabular}


showed additive gene action while protein contents had remarkable heritability (71.13) along with moderate genetic advance (14.14). Glucosinolate also showed high heritability (99.07) and high genetic advance (93.37). For oleic acid and erucic acid high heritability along with remarkable genetic advance were found.

Table 2. Heritability (\%) and Genetic advance (\%) values mean for quantitative traits.

\begin{tabular}{lcc}
\hline Characters & Heritability $(\boldsymbol{\%})$ & $\begin{array}{c}\text { Genetic advance } \\
(\boldsymbol{\%})\end{array}$ \\
\hline DFI & 97.81 & 32.97 \\
D 50\% F & 71.29 & 56.11 \\
D 50\% SF & 94.95 & 89.58 \\
DM & 98.71 & 87.08 \\
PH & 98.40 & 136.72 \\
PB & 79.12 & 8.74 \\
SB & 61.22 & 5.92 \\
GB & 86.37 & 7.05 \\
HI & 80.19 & 5.21 \\
SL/p & 98.95 & 43.93 \\
S/S & 90.04 & 60.46 \\
TSW & 23.83 & 214.53 \\
\hline
\end{tabular}

DFI stands for flowering initiation, D50\% $\mathrm{F}$ for days to $50 \%$ flowering, D50\% SF for days 50\% siliqua formation, DM for days to maturity, PH for plant height, PB for primary branches, SB for secondary branches, GB for green biomass, HI for harvest index, $\mathrm{S} / \mathrm{PL}$ for siliquae per plant, S/S for seed per siliqua, TSW for 100 seed weight.
Table 3. Heritability and genetic advance for quality traits for intraspecific crosses.

\begin{tabular}{lcc}
\hline Quality traits & Heritability & Genetic advance \\
\hline Oil contents (\%) & 94.70 & 17.74 \\
Protein contents (\%) & 71.13 & 14.14 \\
Glucosinolate contents (\%) & 99.07 & 93.73 \\
Oleic acid (\%) & 88.71 & 50.02 \\
Erucic acid (\%) & 97.83 & 119.94 \\
\hline
\end{tabular}

Indirect selection indices for quantitative traits in intraspecific crosses: Correlation studies indicated that genotypic associations were higher than phenotypic associations (Table 4). Plant height had positive remarkable correlations with green biomass, days to $50 \%$ flowering and seed yield per plant. Primary branches had positive significant correlation with secondary branches and secondary branches had negative but significant correlation with seed per siliqua and 100 seed weight. A significant correlation of green biomass was observed with number of siliqua per plant and seed yield per plant. Harvest index had positive association with days to $50 \%$ flowering, days to $50 \%$ siliquae formation, number of seed per siliqua and seed yield per plant. Positive and significant association was found among days to flowering initiation, days to $50 \%$ flowering and days to $50 \%$ siliqua formation. Days to $50 \%$ siliqua formation presented positive and significant correlation with 100 seed weight and highly significant correlation with seed yield per plant. Days to maturity were significantly associated with number of siliqua per plant. Number of siliqua per plant revealed negative

Table 4. Genotypic (upper) and Phenotypic Correlation (lower) between quantitative traits for intraspecific crosses.

\begin{tabular}{|c|c|c|c|c|c|c|c|c|c|c|c|c|c|}
\hline & \multicolumn{5}{|c|}{ Morphological traits } & \multicolumn{4}{|c|}{ Phenological traits } & \multicolumn{4}{|c|}{ Yield related traits } \\
\hline & PH & PB & SB & GB & HI & DFI & D50\% F & D50\% SF & DM & SL/p & $\mathbf{S} / \mathbf{S}$ & TWS & $\mathbf{Y} / \mathbf{P}$ \\
\hline PH & 1.000 & 0.172 & -0.035 & $0.655 * *$ & -0.096 & -0.068 & $0.263 *$ & 0.203 & -0.152 & 0.180 & 0.047 & 57 & $0.269 * *$ \\
\hline PB & 0.142 & 1.000 & $849 * *$ & -0.008 & 0.026 & 34 & 0.032 & 0.092 & 79 & 0.085 & -0.107 & -0.139 & -0.093 \\
\hline SB & -0.032 & $0.753 * *$ & 1.000 & -0.074 & -0.003 & 0.009 & -0.084 & -0.006 & -0.167 & 0.036 & $-0.479 * *$ & $-0.487 * *$ & -0.141 \\
\hline B.Y & $0.644 * *$ & -0.024 & -0.072 & 1.000 & -0.163 & 0.063 & 0.001 & -0.040 & 0.170 & $0.285^{* *}$ & -0.165 & -0.116 & $0.504 * *$ \\
\hline HI & -0.093 & 0.032 & -0.003 & -0.170 & 1.000 & 0.118 & $0.281 * *$ & $0.434 * *$ & 0.019 & 0.191 & $0.329 * *$ & 0.070 & $0.691 * *$ \\
\hline DFI & -0.052 & 0.024 & 0.005 & 0.051 & 0.118 & 1.000 & $0.347 * *$ & $0.398 * *$ & -0.026 & 0.114 & -0.014 & 0.386 & 0.169 \\
\hline $\mathrm{D} 50 \% \mathrm{~F}$ & $0.210^{*}$ & -0.009 & -0.057 & 0.001 & $0.226^{*}$ & $0.387 * *$ & 1.000 & $0.959 * *$ & 0.083 & $0.288^{* *}$ & 0.217 & -0.074 & $0.248^{*}$ \\
\hline $\mathrm{D} 50 \% \mathrm{SF}$ & 0.184 & 0.109 & 0.006 & -0.036 & $0.381 * *$ & $0.338 * *$ & $0.774 * *$ & 1.000 & 0.171 & 0.215 & 0.217 & $0.256^{*}$ & $0.325 * *$ \\
\hline $\mathrm{DM}$ & -0.148 & -0.060 & -0.163 & 0.157 & 0.018 & -0.023 & 0.0263 & 0.139 & 1.000 & $0.269 * *$ & -0.077 & 0.079 & 0.162 \\
\hline $\mathrm{SL} / \mathrm{p}$ & 0.175 & 0.059 & 0.030 & $0.283 * *$ & 0.189 & 0.099 & $0.225^{*}$ & 0.195 & $0.238^{*}$ & 1.000 & 0.017 & $-0.363 * *$ & $0.401 * *$ \\
\hline $\mathrm{S} / \mathrm{S}$ & 0.034 & -0.096 & $-0.439 * *$ & -0.147 & $0.304 * *$ & -0.044 & 0.155 & $0.217 *$ & -0.052 & 0.019 & 1.000 & $0.492 * *$ & 0.184 \\
\hline TWS & -0.021 & -0.054 & $-0.249 *$ & -0.059 & 0.061 & 0.130 & -0.023 & 0.087 & 0.073 & -0.168 & $0.241 *$ & 1.000 & -0.107 \\
\hline $\mathrm{Y} / \mathrm{P}$ & $0.266 * *$ & -0.076 & -0.137 & $0.491 * *$ & $0.687 * *$ & 0.156 & 0.202 & $0.302 * *$ & 0.145 & $0.399 * *$ & 0.172 & -0.044 & 1.000 \\
\hline
\end{tabular}

$*=$ significant $(\mathrm{p}<0.05) ; * *=$ highly significant $(\mathrm{p}<0.01)$.

DFI stands for days to flowering initiation, D50\% F for days to $50 \%$ flowering, D50\% SF for days 50\% siliqua formation, DM for days to maturity, $\mathrm{PH}$ for plant height, PB for primary branches, SB for secondary branches, GB for green biomass, HI for harvest index, S/PL for siliquae per plant, S/S for seed per siliqua, TSW for 100 seed weight, Y/P for yield per plant. 
Ahmad, Sadaqat, Tahir \& Sadia

Table 5. Path analysis for quantitative traits of intraspecific crosses.

\begin{tabular}{|c|c|c|c|c|c|c|c|c|c|c|c|c|}
\hline & \multicolumn{4}{|c|}{ Phenological traits } & \multicolumn{5}{|c|}{ Morphological traits } & \multicolumn{3}{|c|}{ Yield related traits } \\
\hline & DFI & D50\% F & D50\% SF & DM & PH & PB & SB & GB & HI & SL/p & $\mathrm{S} / \mathrm{S}$ & TSW \\
\hline DFI & 0.049 & 0.102 & -0.120 & -0.001 & 0.005 & -0.006 & 0.001 & 0.042 & 0.095 & 0.007 & 0.026 & -0.0004 \\
\hline D $50 \% \mathrm{~F}$ & 0.017 & 0.295 & -0.290 & 0.004 & -0.020 & -0.005 & -0.010 & 0.001 & 0.226 & 0.004 & -0.001 & -0.0019 \\
\hline D $50 \% \mathrm{SF}$ & 0.020 & 0.283 & -0.302 & 0.009 & -0.015 & -0.016 & -0.001 & -0.027 & 0.350 & 0.011 & 0.018 & 0.0004 \\
\hline DM & -0.001 & 0.024 & -0.052 & 0.052 & 0.011 & 0.014 & -0.020 & 0.114 & 0.016 & 0.008 & 0.017 & -0.0013 \\
\hline $\mathrm{PH}$ & -0.003 & 0.078 & -0.061 & -0.008 & -0.075 & -0.029 & -0.004 & 0.438 & -0.077 & 0.010 & -0.006 & -0.0004 \\
\hline PB & 0.002 & 0.009 & -0.028 & -0.004 & -0.013 & -0.171 & 0.102 & -0.005 & 0.021 & 0.007 & 0.004 & 0.0003 \\
\hline SB & 0.000 & -0.025 & 0.002 & -0.009 & 0.003 & -0.145 & 0.120 & -0.049 & -0.002 & 0.003 & -0.009 & 0.0007 \\
\hline B.Y & 0.003 & 0.000 & 0.012 & 0.009 & -0.049 & 0.001 & -0.009 & 0.669 & -0.132 & 0.001 & -0.039 & 0.0025 \\
\hline HI & 0.006 & 0.083 & -0.131 & 0.001 & 0.007 & -0.004 & 0.000 & -0.109 & 0.806 & 0.011 & -0.013 & 0.0006 \\
\hline $\mathrm{SL} / \mathrm{p}$ & 0.006 & 0.085 & -0.065 & 0.014 & -0.013 & -0.015 & 0.004 & 0.190 & 0.154 & 0.038 & 0.001 & 0.0018 \\
\hline $\mathrm{S} / \mathrm{S}$ & -0.001 & 0.064 & -0.066 & -0.004 & -0.004 & 0.018 & -0.057 & -0.111 & 0.265 & 0.001 & 0.081 & -0.0025 \\
\hline TSW & 0.019 & -0.022 & -0.077 & 0.004 & 0.004 & 0.024 & -0.058 & -0.078 & 0.056 & -0.014 & 0.040 & -0.0050 \\
\hline
\end{tabular}

DFI stands for days to flowering initiation, D50\% F for days to 50\% flowering, D50\% SF for days 50\% siliqua formation, DM for days to maturity, PH for plant height, PB for primary branches, SB for secondary branches, GB for green biomass, HI for harvest index, S/PL for siliquae per plant, S/S for seed per siliqua and TSW for 100 seed weight.

Table 6. Phenotypic and genotypic correlation coefficients for quality traits of intraspecific crosses.

\begin{tabular}{lccccc}
\hline Qualitative traits & Oil contents (\%) & $\begin{array}{c}\text { Protein contents } \\
(\%)\end{array}$ & $\begin{array}{c}\text { Glucosinolate } \\
\text { contents (\%) }\end{array}$ & $\begin{array}{c}\text { Oleic acid } \\
(\boldsymbol{\%})\end{array}$ & $\begin{array}{c}\text { Erucic acid } \\
(\%)\end{array}$ \\
\hline Oil contents (\%) & 1.000 & $0.266^{*}$ & -0.242 & -0.030 & 0.203 \\
Protein contents (\%) & 0.167 & 1.000 & $0.621^{* *}$ & $-0.580^{* *}$ & $0.618^{* *}$ \\
Glucosinolate contents (\%) & -0.230 & $0.510^{* *}$ & 1.000 & $-0.579^{* *}$ & $0.510^{* *}$ \\
Oleic acid (\%) & -0.046 & $-0.455^{* *}$ & $-0.564^{* *}$ & 1.000 & $-0.807^{* *}$ \\
Erucic acid (\%) & 0.189 & $0.509^{* *}$ & $0.507^{* *}$ & $-0.777^{* *}$ & 1.000 \\
\hline
\end{tabular}

association with 100 seed weight but positive with seed yield per plant. Number of seed per siliqua reflected direct and considerable relationship with 100 seed weight.

Path coefficient analysis (Table 5) showed that harvest index had considerable positive and direct effect on seed yield per plant (0.806) and positive indirect effect on yield via days to $50 \%$ flowering (0.083). These findings showed that as the harvest index and days to $50 \%$ flowering increase, the yield will also increase. Days to flowering initiation showed positive direct effect (0.049) on seed yield and the highest indirect effect (0.102) via days to $50 \%$ flowering. Days to $50 \%$ siliqua formation had direct effect $(-0.30)$ and indirect positive effect (0.35) via harvest index on seed yield. By reducing the days to 50\% siliqua formation harvest index and seed yield will be increased. Days to maturity exerted positive direct effect $(0.05)$ on seed yield and maximum positive indirect effect (0.11) via green biomass. It indicates that as days to maturity increase, the biological yield will also increase that will ultimately increase in yield. Plant height had negative direct effect $(-0.08)$ while positive direct effect (0.44) via biomass. By reducing the plant height will increase in green biomass yield. Primary branches showed direct effect negatively (-0.17) and maximum indirect effect $(0.10)$ via secondary branches on seed yield. Yield may be increased by reducing the number of primary branches. Positive direct effect (0.12) of secondary branches on seed yield was noted and the highest indirect positive effect $(0.003)$ via number of siliqua per plant. Green biomass had positive direct effect $(0.67)$ on seed yield and the highest indirect positive effect (0.01) via days $50 \%$ siliqua formation. Number of siliqua per plant has direct positive effect (0.03) on seed yield and highest indirect positive effect $(0.19)$ via biological yield on seed yield. Seed per siliqua presented direct effect $(0.08)$ positively on seed yield whilst maximum indirect effects (0.26) positively via harvest index. Negative direct effect of 100 seed weight (-0.005) was recorded for seed yield.

Indirect selection indices for quality traits for intra-specific crosses: Oil content has positive and significant correlation with protein while protein content had considerable positive correlation with glucosinolate and negative significant correlation with oleic acid and significant positive correlation with erucic acid (Table 6). Glucosinolate has positive and significant correlation with erucic acid and negative with oleic acid. Oleic acid was negatively correlated with erucic acid. Protein contents had direct positive effect (.094) and highest indirect effect (.004) via erucic acid on oil contents (Table 7). Glucosinolate contents had direct negative effect ($0.04)$ and indirect effect (0.017) was positive via protein contents. Oleic acid had direct positive effect (.076) and Erucic acid had direct negative effect $(-0.072)$ on oil contents. 
Selection indices in B. campestris $L$.

Table 7. Direct (Diagonal) and indirect effect path coefficients of quality traits.

\begin{tabular}{lcccc}
\hline Quality traits & Protein contents (\%) & Glucosinolate contents (\%) & Oleic acid (\%) & Erucic acid (\%) \\
\hline Protein contents (\%) & $\mathbf{0 . 0 9 4}$ & -0.007 & -0.002 & 0.004 \\
Glucosinolate contents (\%) & 0.017 & $\mathbf{- 0 . 0 4 0}$ & 0.010 & -0.048 \\
Oleic acid (\%) & -0.003 & -0.005 & $\mathbf{0 . 0 7 6}$ & 0.000 \\
Erucic acid (\%) & -0.006 & -0.027 & 0.000 & $\mathbf{- 0 . 0 7 2}$ \\
\hline
\end{tabular}

$*=$ significant $(\mathrm{p}<0.05) ; * *=$ highly significant $(\mathrm{p}<0.01)$

\section{DISCUSSION}

Heritability and genetic advance for intra-specific combinations: Prediction for effective selection is more reliable on heritability along with genetic advance than heritability alone (Johnson et al., 1955) while trait having low genetic advance do not respond the selection (Pant and Singh, 2001). Heritability is the ratio between the genotypic and phenotypic variances and is the outcome of genetically inherited properties of the material and the interaction of the environment in which the experiment is being performed (Falconer and Mackay, 1996). Genetic advance and heritability are the direct selection criteria that determine the degree to which trait respond to selection. So, for achieving further improvement it is necessary to determine the genotypic and environmental effects for the trait being considered. Ali et al. (2003), Amiri-Oghan et al. (2009) and Zare and Sharafzadah (2012) reported similar findings that high heritability along with high genetic advance in percentage of mean indicate heritability was due to additive gene actions and selection for the trait may be effective.

Our results were partially agreed with that of Paikhomba $e t$ al. (2014) for days to $50 \%$ siliqua formation, days to maturity and plant height. Heterosis breeding and population improvement through recurrent selection will be effective because the traits such as number of primary branches, secondary branches, biomass yield and harvest index showed non-additive gene action and selection will not be rewarding in early generations. Findings were not in contrary with results presented by Ali et al. (2003), Aytac et al. (2008) and Mahmud (2008). High heritability and remarkable genetic advance that means additive genetic effects are involved for number of siliquae per plant and number of seed per siliqua as reported by Ali et al. (2003), Aytac et al. (2008), Mahmud (2008). The low heritability and high genetic advance for 100 seed weight were due to additive gene action and selection may be effective in such case. In case of yield both heritability and genetic advance were high and selection will be effective way for the improvement in yield. Observations were agreed with the findings of Singh and Singh (1997) and Sheikh et al. (1999). High heritability along with genetic advance in percentage of mean, prediction can be made for the advancement in Brassica rapa $\mathrm{L}$. through direct selection via traits like days to $50 \%$ siliquae formation, days to maturity, number of siliquae/plant, number of seed per siliqua and plant height.

Heritability and genetic advance for quality traits: Oil contents had high heritability and correlation coefficient is a statistical expression that determines the degree of relationship between two or more variables. In plant breeding, Correlation coefficient describes the relationship among various plant parameters for which selection can be relied on for the genetic improvement of yield. Results were supported by previous findings like (Tyagi et al.1996; Thakral et al., 1998; Oezer et al., 1999; Ghosh and Gulati, 2000; Khan et al., 2006, Aytac and Kinaci, 2009; Zare, 2011) who indicated that positive remarkable correlations of plant height with green biomass, days to $50 \%$ flowering and seed yield per plant but some researchers reported the negative correlation for these traits in rapeseed (Sadaqat et al., 2003; Zare and Shrafzadeh, 2012).

Positive significant correlation of primary with secondary branches was reported by Cheema and Sadaqat (2004). Similar findings on correlation studies for other traits such as secondary branches, seed per siliqua, 100 seed weight, green biomass, number of siliqua per plant, seed yield per plant, harvest index, days to $50 \%$ flowering, days to $50 \%$ siliqua formation, number of seed per siliqua and seed yield per plant were reported by Tyagi et al. (1996), Thakral et al. (1998), Sadaqat et al. (2003) and Zare and Shrafzadeh (2012).

Path analysis for quantitative traits of intraspecific crosses: Path analysis is a standardized partial regression that split the correlation coefficients into measure of direct and indirect effects. Correlation may not provide the comparative value of direct and indirect effect of each yield components on seed yield. Path analysis has been used to know inter-correlation between seed yield and yield contributing traits.

Studies showed that plant height reduction will increase in green biomass yield. Belete (2011) noted direct negative effect on seed yield. However, direct positive effects were also found by Ali et al. (2003). Basalma et al. (2008) also indicated that yield can be increased by reducing the number of primary branches.

Previous findings of Shabana et al. (1990), Ali et al. (2002), Tusar-Patra et al. (2006), Tuncture and Ciftci (2007), Hashmei et al. (2010) and Zare (2011) supported our results for effects of different traits on yield. Ali et al. (2002), Tuncture and Ciftci (2007) and Zare (2011) reported positive direct effect for number of seed per plant while Belete (2011) 
reported negative direct effect of 100 seed weight on seed yield.

Correlation and path analysis for quality traits for intraspecific crosses: Positive relationship between oil and protein content was not supported by Alemeyehu and Becker (2001), who reported negative correlation. Azam et al. (2013) observed that Protein content had positive and significant correlation with erucic acid and none significant with glucosinolate content. Abideen et al. (2013) also reported positive non-significant association between glucosinolate and erucic acid content. Similar findings were supported by Krzymanski and Downey (1969) that oleic acid had negative association with erucic acid. Tahira et al. (2015) also noted that negative direct effect of oil contents on erucic acid and indirect effects via total glucosinolate $(-0.167)$ and oleic acid $(-0.088)$ were also negative. Glucosinolate had positive direct effect (0.384) on erucic acid.

Conclusion: This study showed that selection indices such as plant height, green biomass, harvest index, secondary branches, number of siliquae, days to $50 \%$ siliquae formation, number of seeds per siliqua might be considered for the improvement of seed yield while total protein contents and oleic acid for oil contents.

\section{REFERENCES}

Abideen, S.N.U., F. Nadeem and S.A. Abideen. 2013. Genetic variability and correlation studies in Brassica napus L. genotypes. Int. J. Innov. Appl. Stud. 2:574-581.

Ali, N., F. Javidfar and A.A. Attary. 2002. Genetic variability, correlation and path analysis of its components in winter rapeseed (Brassica napus L.). Pak. J. Bot. 34:145-150.

Ali, N., F. Javidfar, J.Y. Elmira and M.Y. Mirza. 2003. Relationship among yield components and selection criteria for yield improvement in winter rapeseed (Brassica napus). Pak. J. Bot. 35:167-174.

Alemayehu, N. and H.C. Becker. 2001. Variation and inheritance of erucic acid content in Brassica carinata germplasm collections from Ethiopia. Plant Breed. 120:331-335.

Amiri-Oghan, H., M.H. Fotokian, F. Javidfar and B. Alizadeh. 2009. Genetic analysis of grain yield, days to flowering and maturity in oilseed rape (B. napus L.) using diallel crosses. Int. J. Plant Prod. 3:19-26.

Aytac, Z. and G. Kinaci. 2009. Genetic variability and association studies of some quantitative characters in winter rapeseed (Brassica napus L.). Afr. J. Biotech. 8:3547-3554.

Aytac, Z., G. Kinaci and E. Kinaci. 2008. Genetic variation, heritability and path analysis of summer rapeseed cultivars. J. Appl. Biol. Sci. 2:35-39.
Azam, S.M., Farhatullah, A. Nasim, S. Shah and S. Iqbal. 2013. Correlation studies for some agronomic and quality traits in Brassica napus L. Sarhad J. Agric. 29:547-550.

Basalma, D. 2008. The correlation and path analysis of yield and yield components of different winter rapeseed (Brassica napus sp. Oleifera L.) cultivars. Res. J. Agric. Biol. Sci. 4:120-125.

Belete, S.Y. 2011. Genetic variability, correlation and path analysis studies in Ethiopian mustard (Brassica carinata A. Brun) genotypes. Int. J. Plant Breed. Genet. 5:328338.

Bradshaw, J.E. and R.N. Wilson. 1998. Inbred line versus $F_{1}$ hybrid breeding in Swedes (Brassica napus L. var. Napobrassica Peterm). Plant Breed. 113:206-216.

Chauhan, J.S., M.K. Tyagi, P. R. Kumar, P. Tyagi, M. Singh and S. Kumar. 2002. Breeding for oil and seed meal quality in rapeseed mustard in India- A review. Agric. Rev. 23:71-92.

Cheema, K.L. and H.A. Sadaqat. 2004. Potential and genetic basis of drought tolerance in canola (Brassica napus) II. Heterosis manifestation in some morphophysiological traits in canola. Int. J. Agric. Biol. 6:82-85.

Dewey, D.R. and K.H. Lu. 1959. A Correlation and pathcoefficient analysis of components of crested wheatgrass seed production. Agron. J. 51:515-518.

Fahey, J.W. and P. Talay. 1999. Antioxidant functions of sulfor-aphane: a potent inducer of phase II detoxification enzymes. Food Chem. Toxicology. 37:973-979.

Falconer, D.S. and T.F.C. Mackay. 1996. Introduction to Quantitative Genetics, $4^{\text {th }}$ Ed. Longman: Harlow, Netherland.

Ghosh, S.K. and S.C. Gulati. 2001. Genetic variability and association of yield components in Indian mustard (Brassica juncea L.). Crop Res. 21:345-349.

Gupta, S.K. and A. Pratap. 2007. History, origin, and evolution. Adv. Bot. Res. 45:1-20.

Haldane, J.B.S. 1948. The number of genotypes which can be formed with a given number of genes. J. Genet. 49:117119

Johnson, H.W., H.F. Robinson and R.E. Comstock. 1955. Estimation of genetic and environmental variability in soybeans. Agron. J. 47:314-318.

Kempthorne, O. 1957. An Introduction to genetic statistics,. John Welly and Sons, Inc. New York.

Khan, F.A., S. Ali, A. Shakeel, A. Saeed and G. Abbas. 2006. Genetic variability and genetic advance analysis for some morphological traits in B. napus L. J. Agric. Res. 44:8388.

Khulbe, R.K., D.P. Pant and N. Saxena. 2000. Variability, heritability and genetic advance in Indian mustard (Brassica juncea L.). Crop Res. 20:551-552.

Krzymanski, J. and R.K. Downey. 1969. Inheritance of fatty acid composition in winter forms of rapeseed, Brassica napus. Can. J. Plant Sci. 49:313-319. 
Kwon, S.H. and J.H. Torrie. 1964. Heritability and interrelationship among traits of two soybean populations. Crop. Sci. 4:196-198

Mahmood, T., M. Ali, S. Iqbal and M. Anwar. 2003. Genetic variability and heritability estimates in Summer Mustard (Brassica juncea). Asian J. Plant Sci. 2:77-79.

Mahmud, M.A.A. 2008. Intergenotypic variability study in advanced lines of Brassica rapa. M.S. thesis, Sher-eBangla Agricultural University, Department of Genetics and Plant Breeding, Dhaka, Bangladesh. pp.40-69.

Oezer, H., E. Oral and U. Dogru. 1999. Relationship between yield and yield components on currently improved spring rapeseed cultivars. Turkish J. Agric. For. 23:603-607.

Paikhomba, N., A. Kumar, A.K. Chaurasia and P.K. Rai. 2014. Assessment of genetic parameters for yield and yield components in hybrid rice and parents. J. Rice Res. 2: 117 .

Pant, S.C. and P. Singh. 2001. Genetic variability in Indian mustard. Agric. Sci. Digest 21:28-30.

Poehlman, J.M. and D.A. Sleper. 1995. Breeding Field Crops, $4^{\text {th }}$ Ed. Panima, Pub. Corp., New Delhi. pp.75-76.

Sadaqat, H.A., M.H.N. Tahir and M.T. Hussain. 2003. Physiogenetic aspects of drought tolerance in canola (Brassica napus). Int. J. Agric. Biol. 5:611-614.

Shabana, R., S.A. Sharief, A.S. Ibrahim and G. Geisler. 1990. Correlation and path analysis for some new released (00) spring rapeseed cultivar grown under competitive systems. J. Agron. Crop Sci. 165:138-143.

Shaukat, S. Raziuddin, F. Khan and I.A. Khalil. 2014. Genetic variation and heritability estimates of quality traits in Brassica napus L. J. Biol. Agri. Healthcare 4:1-5.

Sheikh, F.A., A.G. Rather and S.A. Wani. 1999. Genetic variability and inter-relationship in toria (Brassica campestris L. var. Toria). Adv. Plant Sci. 12:139-143.

Singh, M. and G. Singh. 1997. Correlation and path analysis in Indian mustard (Brassica juncea L.) under mid hills of Sikkims. J. Hill Res. 10:10-12.

Tahira, R., Ihsanullah, A. Rehman and S. Mahjabeen. 2015. Studies on variability for quality traits, association and path analysis in raya (Brassica juncea) germplasm. Int. J. Agric. Biol. 2:381-386.

Thakral, N., H. Singh, P. Kumar, T.P. Yavada and S.L. Mehta. 1998. Association analysis between physiochemical parameters with seed yield in Indian mustard under normal and saline environments. Crucifereae Newsletter 20:59-60.

Tusar-Patra, S.M. and B. Mitra. 2006. Variability, correlation and path analysis of the yield attributing characters of mustard (Brassica spp.). Res. Crop 7:191-193.

Tyagi, P.K., K. Singh, V. Rao and A. Kumar. 1996. Correlation and path co-efficient analysis in Indian mustard (Brassica juncea L.). Crop Res. Hisar. 11:319322.

Uppstrom, B. 1995. Seed Chemistry. In: D.S. Kimber and D.I. McGregor (eds.), Brassica Oilseeds: Production and Utilization. Wallingford, England: CAB International. pp.217-242.

Weber, C.R. and B.R. Moorthy. 1952. Heritable and nonheritable relationships and variability of oil content and agronomic characteristics in $F_{2}$ generation of soybean crosses. Agron. J. 44:202-209.

Wittkop, B., R.J. Snowdon and W. Friedt. 2009. Status and perspectives of breeding for enhanced yield and quality of oilseed crops for Europe. Euphytica 170:131-140.

Zare, M. 2011. Interrelationship between grain yield and related traits in rapeseed (Brassica napus L.). Afr. J. Agric. Res. 6:6684-6689.

Zare, M. and S. Sharafzadeh. 2012. Genetic variability of some rapeseed (Brassica napus L.) cultivars in Southern Iran. Afr. J. Agric. Res. 7:224-229. 